\title{
Encapsulation of Dirhenium(III) Carboxylates into Zirconium Phosphate
}

\author{
Anastasiia Slipkan, ${ }^{1,2}$ Nataliia Shtemenko, ${ }^{1,2}$ Dina Kytova ${ }^{1,2}$ \\ and Alexander Shtemenko ${ }^{\star, 1}$ \\ ${ }^{1}$ Ukrainian State University of Chemical Technology, Gagarin Ave. 8, Dnipro, Ukraine, 49005 \\ ${ }^{2}$ Dnipro University of Technology, Dmytro Yavornytskiy Ave. 19, Dnipro, Ukraine,49005 \\ * Corresponding author: E-mail: shtemenko@ukr.net \\ Tel.+380 (97) 3929152
}

Received: 08-27-2019

\begin{abstract}
Present work reports the synthesis of zirconium phosphate nanoparticles containing dirhenium(III) substance bis-dimethylsulfoxide-cis-tetrachlorodi- $\mu$-pivalatodirhenium(III) with formula cis- $\mathrm{Re}_{2}\left(\mathrm{C}\left(\mathrm{CH}_{3}\right)_{3} \mathrm{COO}\right)_{2} \mathrm{Cl}_{4} \cdot 2 \mathrm{DMSO}(\mathrm{I})$ and $\theta$-zirconium phosphate with formula $\theta-\mathrm{Zr}\left(\mathrm{HPO}_{4}\right)_{2} \cdot 6 \mathrm{H}_{2} \mathrm{O}(\mathrm{ZrP})$. The intercalation process was monitored by EAS. Due to the spectral characteristics of the quadruple bond the conclusion was made that the obtained intercalated compounds had cis-configuration of ligands around cluster dirhenium fragment. The proposed mechanism of intercalation includes the substitution of the axial ligands of $\mathbf{I}$ by phosphate groups of $\mathrm{ZrP}$ first on the surface of $\mathrm{ZrP}$, than in the inner layers. Two received products of the intercalation were characterized by SEM, XRPD, FT-IR, TGA analysis witnessing about successful intercalation process. The formation of new phases with interlayer distances of 10.53-16.6 $\AA$ was found, the average size of obtained platelets was $100-200 \mathrm{~nm}$.
\end{abstract}

Keywords: Dirhenium(III) carboxylates, zirconium phosphate, nanoparticles, intercalation.

\section{Introduction}

Layered $\mathrm{Zr}(\mathrm{IV})$ phosphates $\mathrm{ZrP}$ with $\alpha, \beta, \gamma$ and $\theta$-structures, $\alpha-\mathrm{Zr}\left(\mathrm{HPO}_{4}\right)_{2} \cdot \mathrm{H}_{2} \mathrm{O}, \beta-\mathrm{Zr}\left(\mathrm{HPO}_{4}\right)_{2} \cdot 2 \mathrm{H}_{2} \mathrm{O}$, $\theta-\mathrm{Zr}\left(\mathrm{HPO}_{4}\right)_{2} \cdot 6 \mathrm{H}_{2} \mathrm{O}$ and $\gamma-\mathrm{ZrPO}_{4} \cdot \mathrm{H}_{2} \mathrm{PO}_{4} \cdot 2 \mathrm{H}_{2} \mathrm{O}$ are well known as convenient, long storing and non-toxic preparations, that due to labile protons of $\mathrm{POH}$ groups can be used for many chemical processes. ${ }^{1,2,3} \mathrm{ZrP}$ is one of the most studied inorganic cation exchange material with high thermal stability, solid-state ion conductivity, resistance to ionizing radiation and is known as a host capable to incorporate different types of guest molecules. ${ }^{4}$

Crystal structure of $\mathrm{ZrP}$ presents a lattice with $\mathrm{Zr}^{4+}$ ions bonding to oxygen atoms from three different phosphate groups producing covalently connected three-dimensional cross-linked planes. The fourth oxygen atom of the tetrahedral phosphate group is protonated and points towards the interlayer space. Water molecules in the interlayer space form hydrogen bonds with hydroxyl groups and are perpendicular to the layer. $\theta-\mathrm{ZrP}$ is a hydrated phase of $\alpha-\mathrm{ZrP}$ and has a similar structure to the $\alpha-\mathrm{ZrP}$ with five additional water molecules in the interlaminar space, thus the distance between the layers increases up to $10.3 \AA$ (Fig. 1A). (Fig. 1A)

Upon dehydration, $\theta-\mathrm{ZrP}$ is converted to $\alpha-\mathrm{ZrP}$ (the distance between the layers is $7.6 \AA$ ) without the formation of any other intermediate phase. ${ }^{5}$ The efficiency of intercalation to all types of $\mathrm{ZrP}$ depends on the distance between the layers and the size of intercalated molecules. ${ }^{6}$ Cations (less than $2.63 \AA$ ) or small molecules can be intercalated within the layers of $\alpha-\mathrm{ZrP}$. However, the intercalation of large cations here was very low. Due to the larger interlaminar space $\theta-\mathrm{ZrP}$ can include large molecules and cations, such as insulin and others ${ }^{6,7}$. That is why among the described modification of $\mathrm{ZrP}$ we chose $\theta-\mathrm{ZrP}$ for our study. It was shown that differences in properties (solubility, charge, polarity) substances such as doxorubicin, insulin, amino acids and various organometallic complexes could be intercalated into ZrP layers. ${ }^{5,6,8-13}$

Dirhenium(III) carboxylates with the unique quadruple bond were described as anticancer, anti-anemic, nephroand hepato-protecting substances, possessing mighty antioxidant properties due to $\delta$-bond unsaturation. ${ }^{14-17}$ Being nontoxic, these compounds present a perspective platform 


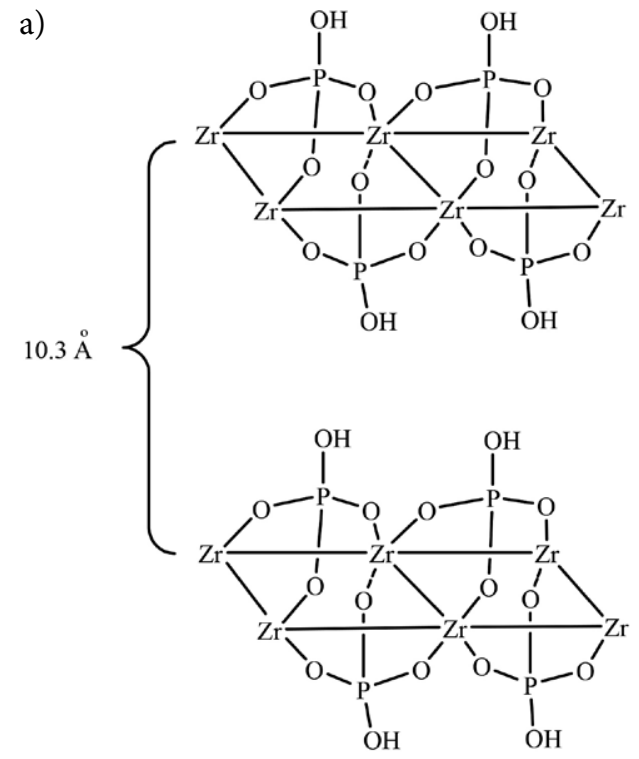

b)

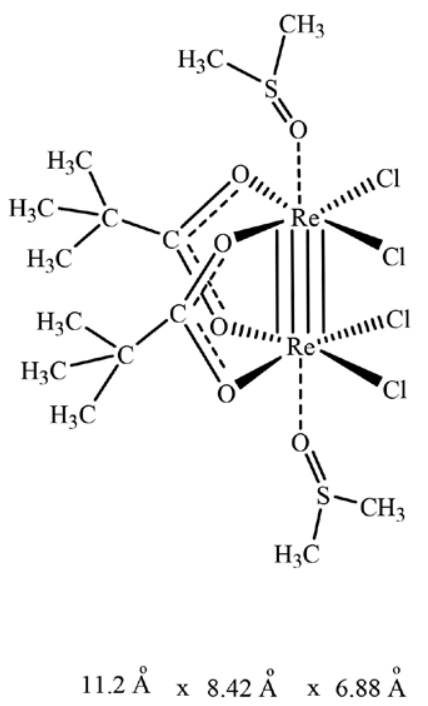

Fig. 1 Structure of $\mathrm{Zr}\left(\mathrm{HPO}_{4}\right)_{2} \cdot 6 \mathrm{H}_{2} \mathrm{O}(\theta-\mathrm{ZrP})$ (a) and cis- $\mathrm{Re}_{2}\left(\mathrm{C}\left(\mathrm{CH}_{3}\right)_{3} \mathrm{COO}\right)_{2} \mathrm{Cl}_{4} \cdot 2 \mathrm{DMSO}$ (I) (b) with linear dimensions.

for the creation of a new class of Re-containing medicines. Bis-dimethylsulfoxide-cis-tetrachlorodi- $\mu$-pivalatodirhenium(III) of common formula cis- $\mathrm{Re}_{2}\left(\mathrm{C}\left(\mathrm{CH}_{3}\right)_{3} \mathrm{COO}\right)_{2} \mathrm{Cl}_{4}$. $2 \mathrm{DMSO}(\mathrm{I})$ and structure shown on the Fig.1B was studied in the model of tumor-growth and showed essential antioxidant and anticancer activities as a component of the antitumor rhenium-platinum antitumor system. ${ }^{18,19}$ Among them the substances with superoxide dismutase activity and abilities to interact with proteins were found. The valuable biological properties of these compounds were better realized in the forms of liposomes, than in water solutions, ${ }^{20,21}$ that occurred due to lipid layer protection of dirhenium substances from hydrolysis and also by existing of the equilibrium inside the liposome, that enhanced chemical potential of the preparations. Thus, the approach to create nanocarriers for delivery of the quadruple-bonded complexes is very promising.

The $\mathrm{ZrP}$ nanoplatelets may be prepared by methods of intercalation or exfoliation [22]. The last method had some disadvantages, for example, the necessity of the preintercalator, which may be toxic. That's why we consider it reasonable to use the intercalation procedure.

Thus, taking into account all the above, the aim of the present work was to investigate the process of intercalation of cis- $\mathrm{Re}_{2}\left(\mathrm{C}\left(\mathrm{CH}_{3}\right)_{3} \mathrm{COO}\right)_{2} \mathrm{Cl}_{4} \cdot 2 \mathrm{DMSO}(\mathrm{I})$ into $\theta-\mathrm{ZrP}$ and to obtain $\mathrm{I} / \mathrm{ZrP}$ nanoplatelets by intercalation method.

\section{Experimental Section}

\section{1. Materials and Methods}

All used chemicals were of analytical grade purity. $\theta$ - $\mathrm{ZrP}$ was obtained according to ${ }^{5}$ with some modifications (see below). cis- $\mathrm{Re}_{2}\left(\mathrm{C}\left(\mathrm{CH}_{3}\right)_{3} \mathrm{COO}\right)_{2} \mathrm{Cl}_{4} \cdot 2 \mathrm{DMSO}(\mathrm{I})$ was obtained according to. ${ }^{16}$

\section{2. Synthetic Methods}

Synthesis of $\theta-Z r P: 200 \mathrm{ml}$ of $0.05 \mathrm{M}$ water solution of $\mathrm{ZrOCl}_{2} \cdot 8 \mathrm{H}_{2} \mathrm{O}$ was added to preheated up to $94^{\circ} \mathrm{C} 200 \mathrm{ml}$ of $6 \mathrm{M} \mathrm{H}_{3} \mathrm{PO}_{4}$ in a $500 \mathrm{ml}$ round bottom flask. The resulting solution was constantly stirred at $94^{\circ} \mathrm{C}$ for $48 \mathrm{~h}$. The product was a crystalline precipitate centrifuged and washed several times with water.

Synthesis of $\mathbf{I} / \theta-Z r P$ composites. The process of intercalation of $\mathbf{I}$ in $\theta-\mathrm{ZrP}$ was conducted in isopropyl alcohol (IPA), not in the water, to avoid possible hydrolytic processes of dirhenium(III) complexes. First, the suspension of $I$ and $\theta-Z r P$ in IPA in the molar ratios of $I$ and $\theta-Z r P ~ 1: 5$ and 1:30 was prepared: the required amount of $\theta-\mathrm{ZrP}$ was suspended in $5.0 \cdot 10^{-3} \mathrm{M}$ solution of $\mathbf{I}$. The molar ratios of I/ $/-\operatorname{ZrP} 1: 5$ and $1: 30$ were taken according to the similar investigations of the intercalation process between $\theta-\mathrm{ZrP}$ and platinides. ${ }^{23}$ Then the suspension was stirred vigorously at $60^{\circ} \mathrm{C}$ for 5 days. The intercalation process was controlled by each day measurements of $\mathrm{pH}$ and UV-Vis absorption spectra (EAS) of the supernatant of a centrifuged aliquot. Constant $\mathrm{pH}$ and UV-Vis absorbance indicated the end of the intercalation process. The reaction mixture was cooled, centrifuged (micro-centrifuge type 320; Mechanika Precyzyjna, Poland) at $14000 x g$, filtered, washed three times with IPA, dried and weighted. As a result of the intercalation, the mass of the $\mathrm{I} / \theta-\mathrm{ZrP}$ of $1: 5$ and 1:30 molar ratio increased on $0.57 \mathrm{~g}$ (26\% of the substance was intercalated) and $1.45 \mathrm{~g}$ (66\% of the substance was intercalated) correspondingly.

\section{3. Measurements}

$\mathrm{pH}$ was controlled by $\mathrm{pH}$-meter-millivoltmeter pH-150 MA. UV-vis absorption spectra were measured 
in IPA using spectrophotometer "Specord M-40" (Germany).

Calculations of three-dimension structures and linear dimensions were made with the help of the Mercury (Mercury for Windows, version 3.6 using the crystal structure of $\mathbf{I}^{16}$ ) program for crystal structure visualization, exploration and analysis.

Scanning electron micrographs (SEM) of the samples were performed using a Tescan Mira 3 LMU scanning electron microscope at an acceleration voltage of $30 \mathrm{kV}$. Samples were prepared using Digiprep 251 and MicraCut 151 (Metkon). The speed of rotation of the disk $-50-600$ $\mathrm{rpm}$, the speed of rotation of the samples 50-150 rpm.

Zeta potentials of $\mathrm{ZrP}$ nanoplatelets were determined using Zeta Sizer Nano S (Malvern, UK) at $25^{\circ} \mathrm{C}$ at $\mathrm{pH} 7.4$.

$\mathrm{X}$-ray diffraction (XRPD) measurements were performed from 5 to $60^{\circ} \mathrm{C}$ using X-ray diffractometer PANalytical X'Pert High Score with a copper anode source $\left(\mathrm{K}_{\alpha 1}\right.$, $\lambda=1.5406 \AA$ ).

IR spectra were recorded in the range of the 4000 $400 \mathrm{~cm}^{-1}$ in dehydrated $\mathrm{KBr}$ tablets in infrared spectrophotometer FT-IR Spectrum BX, (Perkin Elmer).

Thermogravimetric analysis (TGA analysis) was conducted on the derivatograph Q-1500D Paulik-Paulik-Erday on the air in the interval $20-1000{ }^{\circ} \mathrm{C}$ with the speed $10^{\circ} \mathrm{C} / \mathrm{min}$ of temperature changing. $\alpha-\mathrm{Al}_{2} \mathrm{O}_{3}$ served as an etalon. The error in determined temperature intervals was not more than $5 \%$. After that, another modification of thermal destruction investigation, i.e. method of thermal exposures was used. The weighted sample of the substance was placed in the glass reactor for thermal expo-

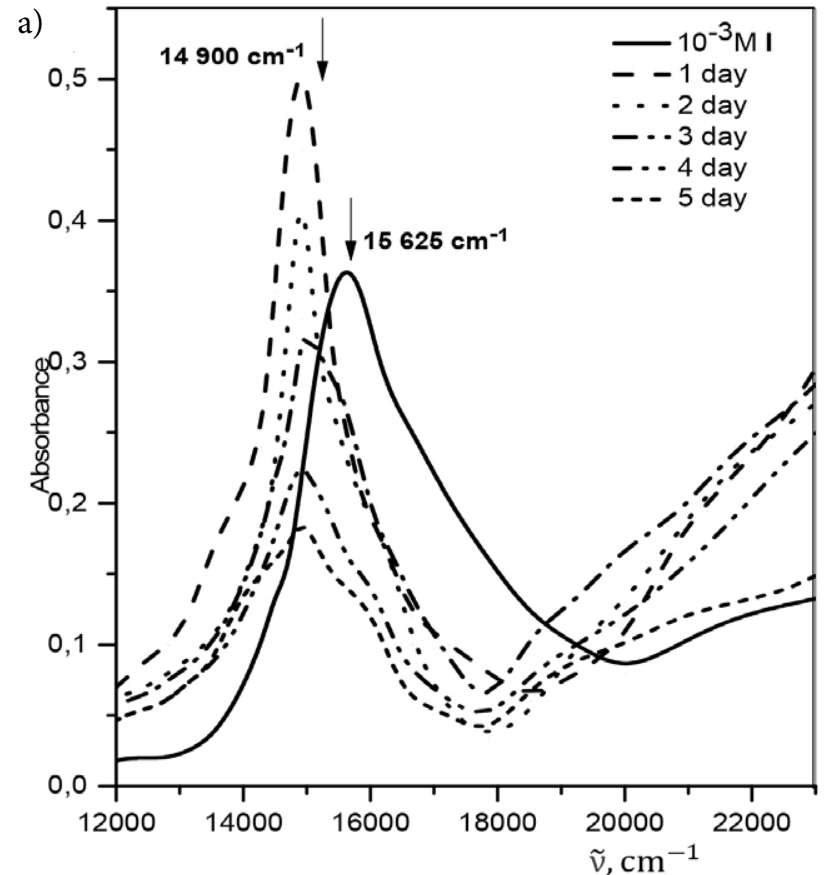

sures and was heated in an inert atmosphere under the temperatures of earlier determined temperatures of the weight losses during $4 \mathrm{~h}$. After each exposure, the sample was weighed and the weight loss was determined.

The drug encapsulation efficiency (EE) of the composites was measured by spectrophotometric method according to at different time intervals at $14900 \mathrm{~cm}^{-1}$ using Eq. (1):

$$
\begin{aligned}
\mathrm{EE}(\%)= & {[(\text { Total } \mathbf{I}-\mathbf{I} \text { in supernatant }) /} \\
& \text { Total } \mathbf{I}] \times 100 \%
\end{aligned}
$$

\section{Results and Discussion}

\section{1. Spectral Investigation of Intercalation I with ZrP.}

Spectral analysis was used by us to investigate interactions of different types of dirhenium cluster compounds with 1-palmitoyl-2-oleylphosphatidylcholin (POPC) preparation of liposomes, ${ }^{20,24}$ proteins ${ }^{25}$ and zirconium phosphate ${ }^{26,27}$ due to ability of the quadruple bond to absorb in the visible area.

Different structural types of $\mathrm{Re}_{2}{ }^{6+}$ derivatives had the characteristic absorption maxima in the visible area, the position of which were dependent from the quantity of hyperconjugated cycles around $\mathrm{Re}_{2}{ }^{6+}$ center. The effect of hyperconjugation was realized due to the interaction of the delocalized $\pi$-bond of $\mu$-carboxylic ligands group and the $\delta$-component of the quadruple Re-Re bond. If dichlorotetra- $\mu$-isobutiratodirhenium(III) $\quad \mathrm{Re}_{2}(\mathrm{i}-\mathrm{PrCOO})_{4} \mathrm{Cl}_{2}$ had

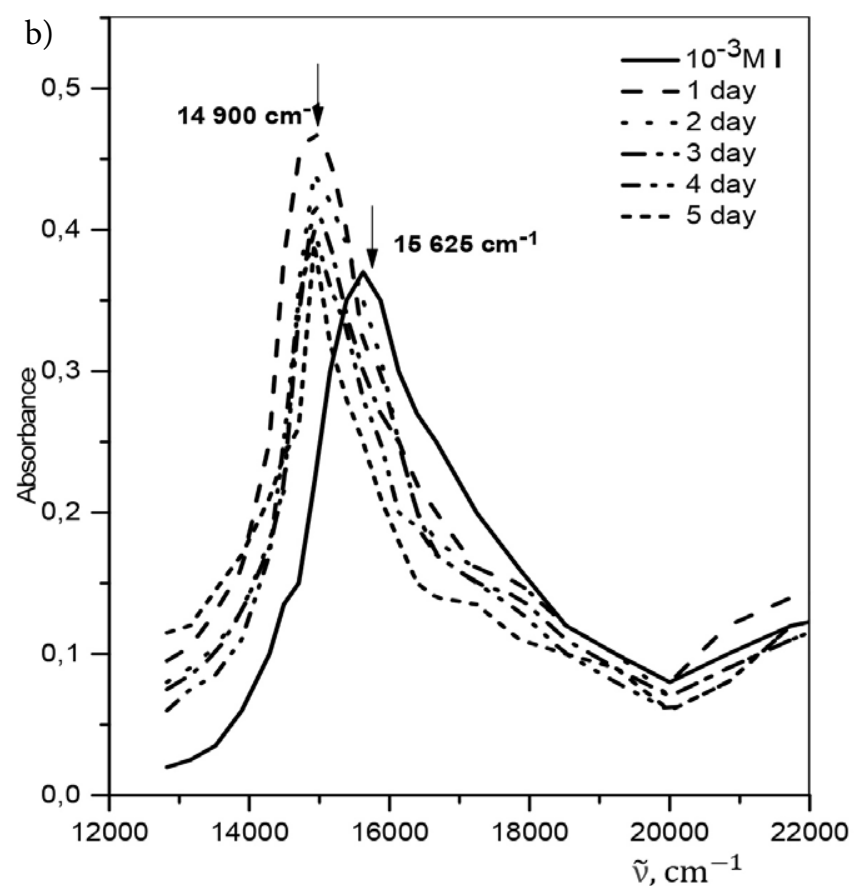

Fig. 2 EAS of the reaction mixture of $\mathrm{I}\left(10^{-3} \mathrm{M}\right)$ and $\mathrm{ZrP}$ in IPA: a) at 1:30 ratio over time; b) at 1:5 ratio over time; control - IPA 
maximum absorption in the area $20000 \mathrm{~cm}^{-1}$, the bidentate coordinated tetra- $\mu$-phosphates $\left[\mathrm{Re}_{2}\left(\mathrm{HPO}_{4}\right)_{4}\left(\mathrm{H}_{2} \mathrm{O}\right)_{2}\right]^{2-}$ and $\left[\mathrm{Re}_{2}\left(\mathrm{HPO}_{4}\right)_{2}\left(\mathrm{H}_{2} \mathrm{PO}_{4}\right)_{2}\left(\mathrm{H}_{2} \mathrm{O}\right)_{2}\right] \cdot 4 \mathrm{H}_{2} \mathrm{O}$ had the $\delta \rightarrow \delta^{*}$ absorption band at $15625 \mathrm{~cm}^{-1}$. The replacement of carboxylic ligands on phosphate or chlorine groups would shift the absorption band $\delta \rightarrow \delta^{*}$ to low energy region (bathochromic shift). So, the analogical spectral picture was expected to be seen in the present experiment.

Before starting the experiment, two important measurements were done: 1 . The spectrum of $\mathrm{ZrP}$ in IPA was investigated, and no absorption in the area 12000-22000 $\mathrm{cm}^{-1}$ was detected; 2 . The solution of I in IPA in concentration $10^{-3} \mathrm{M}$ was heated at $60^{\circ} \mathrm{C}$ during 5 days with spectral investigations and it was found that the intensity of the characteristic band of I $\left(15625 \mathrm{~cm}^{-1}\right)$ was not changed. These measurements supported the idea, that any changes in the investigated area of the spectrum should be the reason of $\mathbf{I}$ and $\mathrm{ZrP}$ interactions.

On figure 2, EAS of the reaction mixtures of $\mathbf{I}$ with $\mathrm{ZrP}$ at 1:30 and 1:5 molar ratio over time are presented.

In both variants of the experiment, the sharp increase of intensity of the characteristic bond was noticed together with the shift from $15625 \mathrm{~cm}^{-1}$ to $14900 \mathrm{~cm}^{-1}$ that definitely indicated that there was an interaction of $\mathbf{I}$ with $\mathrm{ZrP}$ and formation of new complexes of $\mathbf{I}$ with phosphate groups from $\mathrm{ZrP}(\mathrm{I} / \mathrm{ZrP})$ on the surface layers. Then the decrease of the intensity of the band $14900 \mathrm{~cm}^{-1}$ took place. To our mind, during the following process of intercalation, the concentration of I decreased due to penetration of $\mathbf{I}$ to interlayer space of $\mathrm{ZrP}$. As more molecules of $\mathbf{I}$ penetrated to interlayer space and formed new complexes, as more the equilibrium $\mathbf{I}+\mathrm{ZrP} \leftrightarrow \mathbf{I} / \mathrm{ZrP}$ was shifted to the side of the intercalation and formation of new complexes and accordingly we watched the decreasing of the characteristic band $14900 \mathrm{~cm}^{-1}$.

Earlier it was shown by us, that dicarboxylates of dirhenium(III) reacted with POPC by substitution of axial chlorine groups on phosphate groups. ${ }^{20,24}$ In our experiment we investigated the little bathochromic shift in the area of quadruple bond absorption that may propose the substitution of the carboxylic groups by phosphate from ZrP. But, it was proved, that dicarboxylates reacted with POPC by another type, i.e. by substitution of chlorine atoms on phosphate groups. ${ }^{20,24}$

The interaction of dicarboxylates with POPC was followed by a decrease of the bands $15400-15700 \mathrm{~cm}^{-1}$ and concomitant appearance of a new band at $12133 \mathrm{~cm}^{-1}$, the intensity of which increased dramatically with time. ${ }^{24}$ These two features are characteristics of a $\operatorname{Re}_{2}(\delta) \rightarrow \operatorname{Re}_{2}\left(\delta^{*}\right)$ electron transition for trans-dicarboxylates. ${ }^{15}$ The process possibly involves the substitution of the chloride groups of dicarboxylates by POPC via oxygen atoms from the phosphate groups which initiates a cis-trans rearrangement of the bridging carboxylate ligand.

In our experiments, we did not detect the appearance of absorption in the area $12000 \mathrm{~cm}^{-1}$ that confirmed

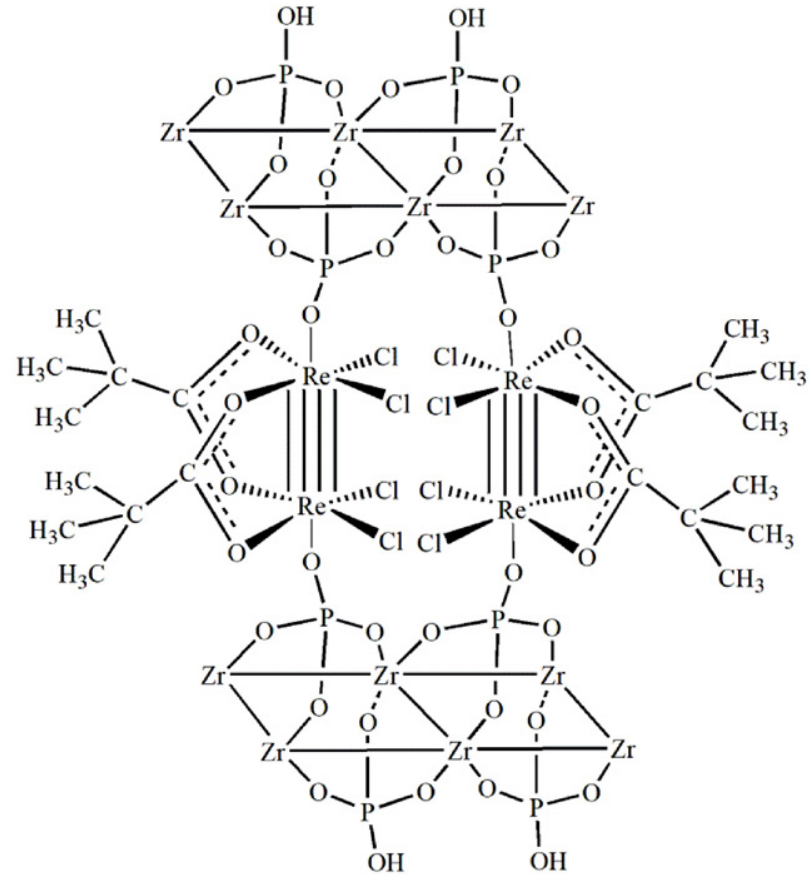

Fig. 3 The proposed formula of the product of the reaction between I and phosphate groups on the surface layers of $\mathrm{ZrP}$

another mechanism of interaction without the formation of trans-product. Thus, the possible explanation of the spectral characteristic of the reaction mixture is the substitution of the DMSO in I by phosphate groups of $\mathrm{ZrP}$ without the formation of trans-derivatives and the only obtained product is the presented one on the Fig. 3 with remained cis-configuration.

It is necessary to note, that the quadruple bond between two rhenium atoms has unique spectral properties: first to absorb in the visible area due to the $\delta \rightarrow \delta^{\star}$ transition of the spectrum, where no other organic molecules can absorb; second very important property of the band is the dependence of absorption from the number of organic ligands around cluster $\mathrm{Re}_{2}{ }^{6+}$ fragment and their orientation. These two facts make it possible to demonstrate the mechanism of intercalation of the dirhenium(III) compound, which includes the modification of $\mathrm{ZrP}$ surface due to the coordination of its phosphate groups to the Re-Re core at first. Then the intercalation took place in $\mathrm{ZrP}$ inner layers. As to our knowledge, such mechanisms have not been shown yet for any intercalated substance.

\section{2. SEM}

The SEM images of $\mathbf{I} / \mathrm{ZrP}$ intercalation product 1:30 and 1:5 showed that hexagonal like shape of initial $\mathrm{ZrP}$ was stored (Fig. 4).

The average diameter of platelets is $104 \mathrm{~nm}$ for 1:30 adduct (Fig. 4A) and $120 \mathrm{~nm}$ for 1:5 adduct (Fig. 4B). The thickness for them is approximately $15.7 \mathrm{~nm}$ and $24.5 \mathrm{~nm}$ accordingly (Fig.4 C, D). 

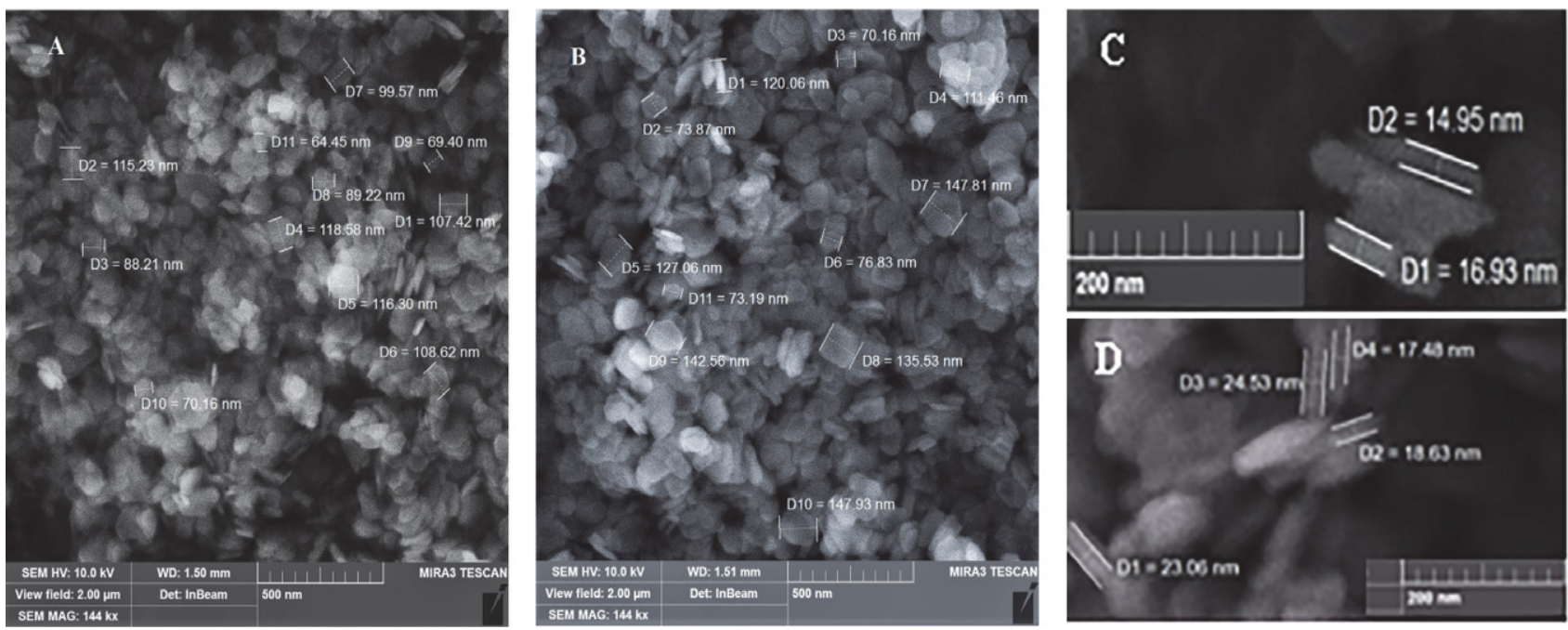

Fig. 4 The SEM images of the I/ZrP: A, C - 1:30, B,D - 1:5

Since the phosphate groups of $\mathrm{ZrP}$ are directed down and up relative to the plane, the rhenium(III) complex can coordinate on the surface of the nanoparticles as well. Such surface modification of $\mathrm{ZrP}$ with I was proved by EDX of intercalated material. Fig. 5 shows that the EDX spectrum for the I/ZrP intercalated product includes the characteristic peak indicating the presence of $\operatorname{Re}(8.1 \%)$ on the surface of the nanoparticles.

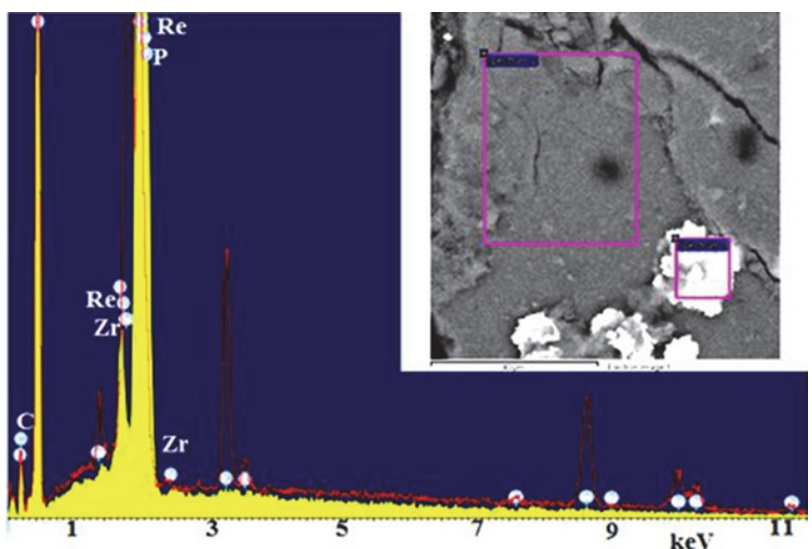

Fig. 5 EDX spectrum of I/ZrP 1:5

Zeta potential of both preparations $\mathbf{I} / \mathrm{ZrP}$ is $-37 \pm 2$ $\mathrm{mV}$ showing that obtained nanoplatelets are stable in an aqueous medium. ${ }^{12}$ The obtained nanoparticles have a platelet-like shape. Such shapes were shown to have some advances in comparison to spherical ones due to better adhesion, margination and binding properties. For example, the binding probability of nanorods was found to be three times higher than that of nanospheres with the same volume. ${ }^{28}$ The obtained SEM data together with spectral investigations point that $\mathrm{ZrP}$ can be used as a matrix for cluster rhenium(III) with cis-configuration of carboxylate ligands.

\section{3. X-ray Powder Diffraction}

The reaction of intercalation of $\mathbf{I}$ into interlayers is topotactic, ${ }^{6}$ i.e. solid-phase reaction during which the packaging of atoms in the crystal of the reagent is practically the same, only distances between some atoms in several directions are changing. The diffraction peaks at the lowest $2 \theta$ angle correspond to the interlayer distance which depends on the intercalated substance. ${ }^{29}$ The XRPD patterns of $\mathbf{I} / \mathrm{ZrP}$ for molar ratios 1:30 and 1:5 show the appearance of new peaks (Fig. 6 B, C), indicating the formation of new phases.

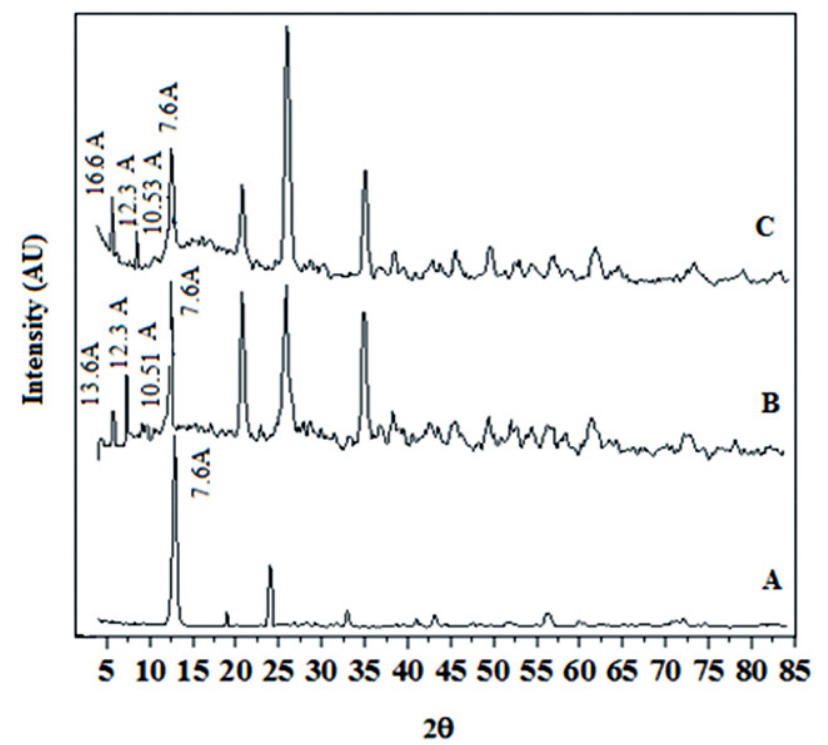

Fig. $6 \mathrm{X}$-ray diffraction $\alpha-\mathrm{ZrP}(\mathrm{A}), \mathrm{I} / \mathrm{ZrP} 1: 30$ (B) and $\mathrm{I} / \mathrm{ZrP}=1: 5$ (C)

In the absence of intercalated substances, the distance between layers of $\alpha$-ZrP corresponds to $7.6 \AA$ (Fig. $6 \mathrm{~A}$ ). The presence of this peak in the diffraction patterns of the intercalation products indicates that formed phases are 
mixed. The intensity of this peak is lower in patterns $B$ and $\mathrm{C}$ than in $\mathrm{A}$, pointing to the reduction of this phase with increasing concentration of $\mathbf{I}$.

Formations of new phases are followed with appearance of first-order diffraction peak $13.59 \AA$ for $\mathbf{I} / \mathrm{ZrP} 1: 30$ (Fig. 6B) and $16.6 \AA$ for $\mathrm{I} / \mathrm{ZrP}=1: 5$ (Fig. 6C); besides, both composites show the second and the third peaks: $12.28 \AA$ and $10.53 \AA$ for I/ZrP 1:30 (Fig. 6B); $12.3 \AA$ and $10.51 \AA$ for $\mathrm{I} / \mathrm{ZrP}=1: 5$ (Fig. $6 \mathrm{C}$ ).

Three-dimensional structure and lineal dimensions of $\mathbf{I}$ are presented on Fig. 7.

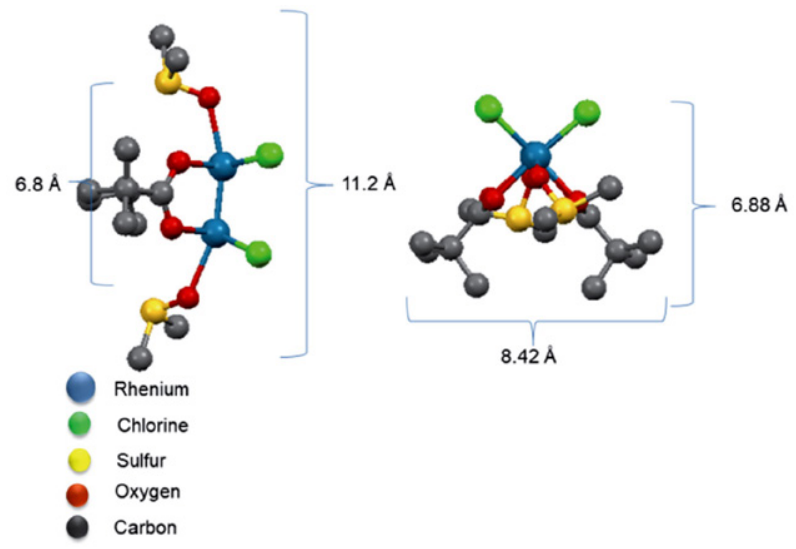

Fig. 7 Structure of I showing its dimensions as calculated by Mercury

If lineal dimensions for I molecule are known $11.2 \mathrm{x}$ $8.42 \times 6.88 \AA 3$ and are presented on the Fig. 7, and interlayer distance in $\mathrm{ZrP}$ is also known to be $6.6 \AA$, this allows us to predict the interlayer distances in the newly formed phases and approximate coordination of the I molecules between $\mathrm{ZrP}$ layers. For instance, for $\mathrm{I} / \mathrm{ZrP} 1: 30$ the shown interlayer distance $13.59 \AA$ may correspond to disposition of I molecules parallel to ZrP layers $(6.88 \AA+6.6 \AA=13.48$ $\AA$ ); accordingly the diffraction peak $16.6 \AA$ may correspond to perpendicular disposition of I to $\mathrm{ZrP}$ layers (11.2 $\AA+6.6 \AA=17.8 \AA$ ). A little decrease between calculated and real distances may be explained by compressing of $\mathrm{ZrP}$ layers and/or by hiding (interaction) of branched ligands of I into so-called "pockets" of ZrP. ${ }^{6}$

Thus, the analysis of XRPD patterns of newly synthesized $\mathbf{I} / \mathrm{ZrP}$ products gives confirmation about the forma- tion of new intercalated products and imagination about a possible disposition of $\mathbf{I}$ between layers of $\mathrm{ZrP}$.

\section{4. FT-IR Data.}

The obtained FT-IR data for I/ZrP 1:30 and 1:5 were identical, so we demonstrate data only for the first one in comparison with primary substances (Fig. 8).

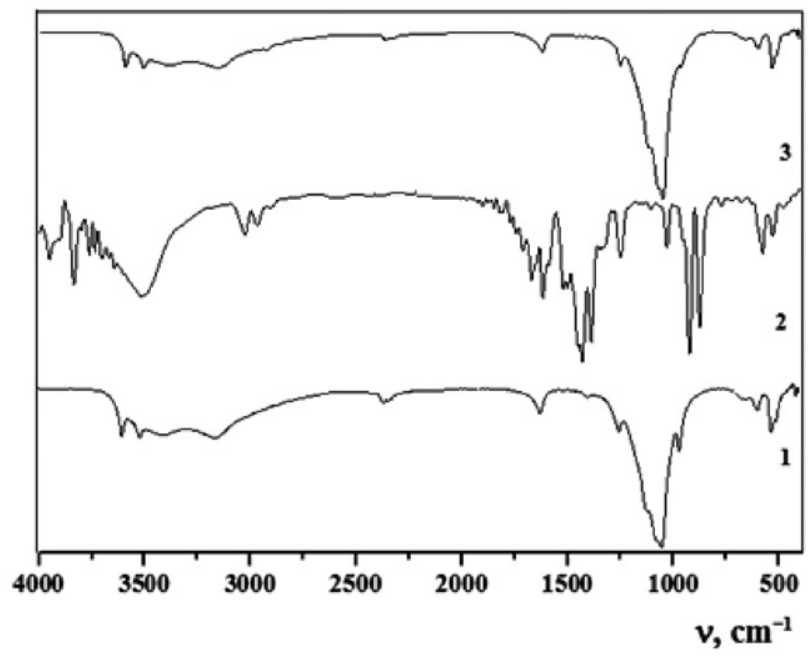

Fig. 8 FT-IR spectra of ZrP (1); I (2); I/ZrP 1:30 (3)

The data presented in the table and in the Fig. 8 show the disappearance of the absorption bands in I/ZrP 1:30 characteristic for $\mathbf{I}$ structure, indicating that $\mathbf{I}$ is absent on the surface of the composite and support the earlier speculations about successful intercalation procedure. The only difference in spectra of initial $\mathrm{ZrP}$ and the complex $\mathrm{I} / \mathrm{ZrP}$ is the absence of the band $1100-940 \mathrm{~cm}^{-1}$ in the last one referred to fluctuations of phosphate groups that may occur due to involvement of phosphate groups in the reaction.

\section{5. TGA Analysis.}

Thermograms of both intercalation products show three weight losses (Fig.9).

First weight loss under $120^{\circ} \mathrm{C}$ corresponds to the loss of coordinated water in zirconium phosphate; the second

Table 1: Characteristic frequencies $\left(\mathrm{cm}^{-1}\right)$ and their correspondence in the FT-IR spectra of I, $\mathrm{ZrP}$ and I/ZrP 1:30

\begin{tabular}{|c|c|c|c|c|c|c|}
\hline Substance & $v_{s}(C O)$ & $\begin{array}{c}\delta_{a s}, v_{s} \\
\left(\mathrm{C}\left(\mathrm{CH}_{3}\right)_{3} \mathrm{COO}-\right)\end{array}$ & $\begin{array}{l}v_{s}\left(\mathrm{H}_{2} \mathrm{O}\right) \\
v_{s}(\mathrm{OH}-)\end{array}$ & $\begin{array}{c}v_{s} \\
(D M S O)\end{array}$ & $\begin{array}{c}v_{s}(P-O) \\
v_{s}(P-O H)\end{array}$ & $v_{s}(M-O)$ \\
\hline I & 1420 & $\begin{array}{c}2800 \\
1470-1430\end{array}$ & 3500 & $1225-980$ & - & $390-480$ \\
\hline $\mathrm{ZrP}$ & - & - & $\begin{array}{l}1620 \\
3500\end{array}$ & - & $\begin{array}{c}1200 \\
1100-940\end{array}$ & 522 \\
\hline $\begin{array}{l}\mathrm{I} / \mathrm{ZrP} \\
1: 30\end{array}$ & - & - & $\begin{array}{l}1620 \\
3500\end{array}$ & - & 1200 & 522 \\
\hline
\end{tabular}


a)

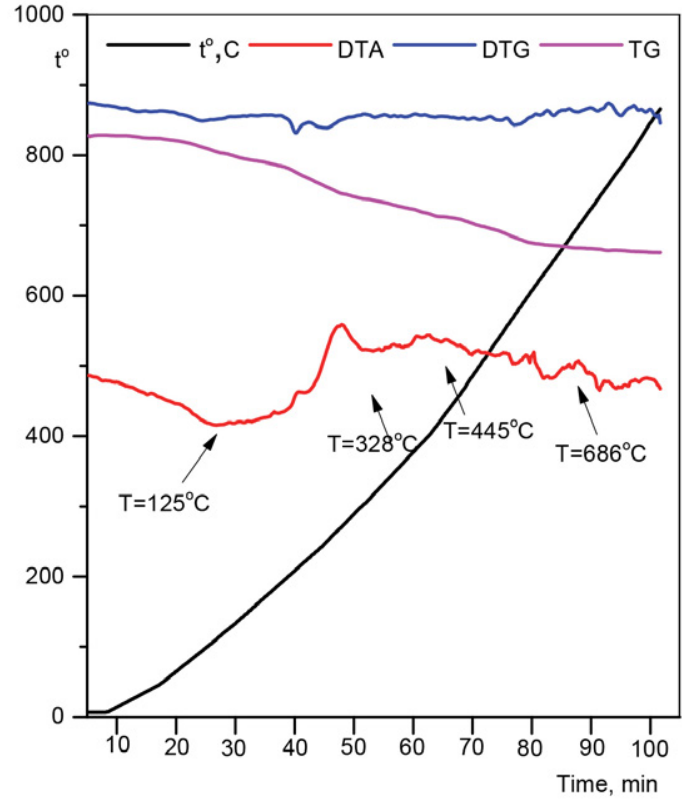

Fig. 9 Thermograms of I/ZrP: a) I/ZrP 1:5; b) I/ZrP 1:30.

under $250-350{ }^{\circ} \mathrm{C}$ - to the thermo destruction of I with the formation of the trans-isomer; ${ }^{30}$ and the third - to condensation of phosphate groups and the formation of zirconium pyrophosphate. ${ }^{31}$

The weight losses in the first and second stages of thermograms for the I/ZrP 1:5 were: 9\%; 13.2\% (Fig. 9A) and for the I/ZrP 1:30 9\%; 10\% (Fig. 9B). Low levels of weight loss could be the result of quickly temperature increasing, so we decided to undertake another modification of thermal destruction investigation (see Materials and methods), i.e. method of thermal exposures. In this modification method following weight losses for the $\mathrm{I} / \mathrm{ZrP} 1: 5$ were: $8.87 \%$ under $120{ }^{\circ} \mathrm{C}$; $29.89 \%$ under $250-350{ }^{\circ} \mathrm{C}$ of heating and for $\mathrm{I} / \mathrm{ZrP} 1: 309.8 \%$ and $10.9 \%$ accordingly.

\section{6. Drug Loading Studies.}

The time-depending drug encapsulation efficiency (EE) studies of I/ZrP 1:5 and I/ZrP 1:30 (Fig. 10) showed not so rapid uptake of $\mathbf{I}$ as it was found for example for curcumin $(120 \mathrm{~min}) .^{2}$

This may be explained by more necessary time for the reaction of substitution in comparison with time for the formation of hydrogen bonds between the hydroxyl groups of curcumin and negatively charged phosphate groups of $\mathrm{ZrP}$. The maximum EE (66\%) was reached only on the 5th day for $\mathbf{I} / \mathrm{ZrP} 1: 30$ and $26 \%$ for $\mathbf{I} / \mathrm{ZrP} 1: 5$.

Our further investigations are aimed at obtaining the mixed composites (for example I + cisplatin, or I + doxorubicin) and on studying their biological activities. This direction is very promising due to the following reasons: anticancer properties of solely introduced I and some alkyl carboxylates were not very essential, as it is known about introduction of other cytostatics; the group of Prof. A. b)
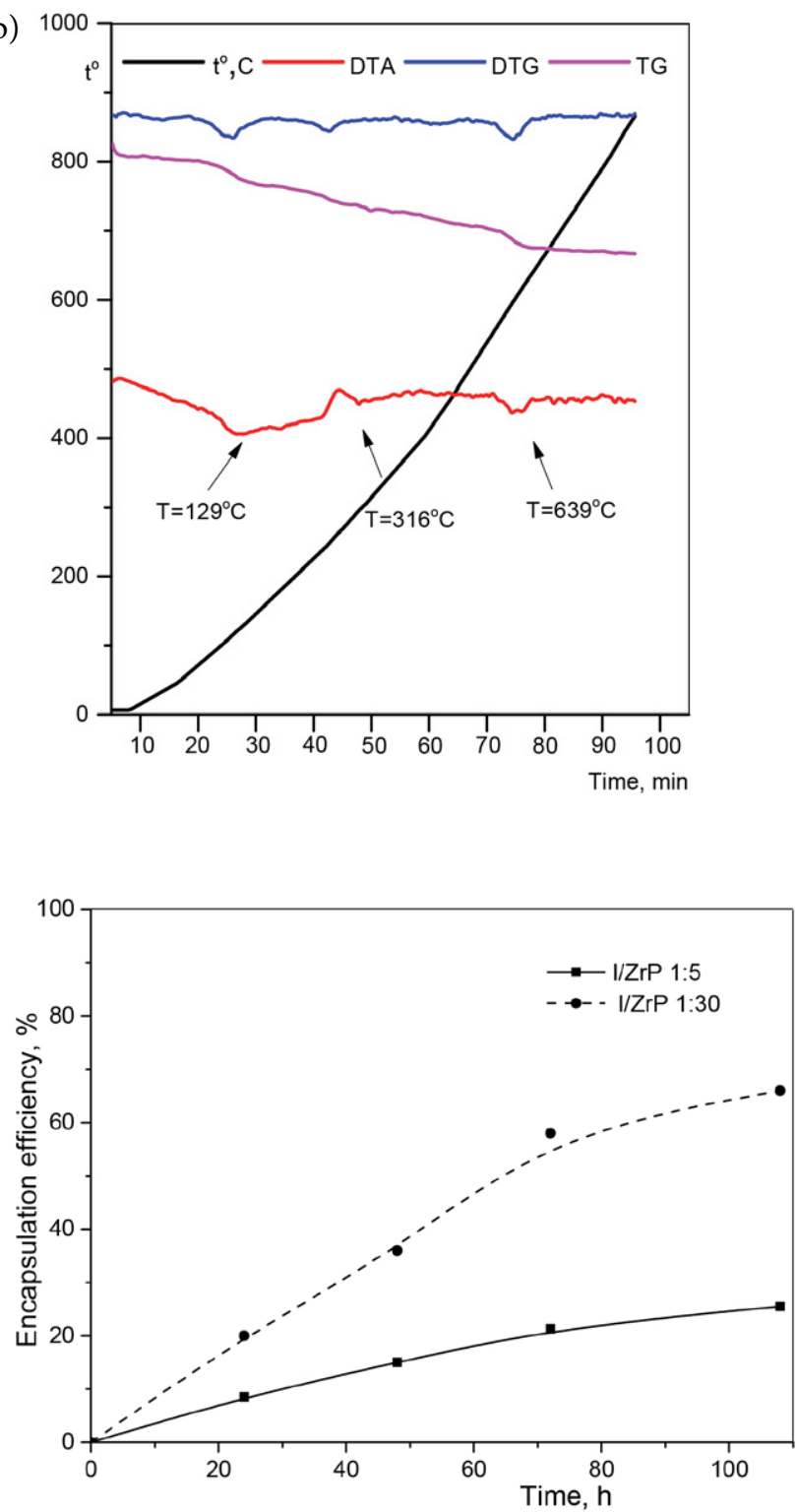

Fig. 10 Time-dependent I encapsulation efficiency of ZrP nanoplatelets

Clearfield recently have shown good perspectives of $\mathrm{ZrP}$ composites as medicines ${ }^{31,32}$ as in several biological models ZrP-composites were shown to be more active than free substances.

\section{Conclusions}

The method of intercalation of $\mathbf{I}$, the representative of cis-carboxylate of dirhenium(III) compounds, into $\theta-\mathrm{ZrP}$ was elaborated. The possible mechanism of intercalation is the substitution of the axial ligands by the layers phosphate groups to the cluster center $\operatorname{Re}_{2}{ }^{6+}$ producing new phases with interlayer distances of 10.53-16.6 $\AA$ and the average size of platelets $100-200 \mathrm{~nm}$. Two received 
products of the intercalation process were characterized by appropriate methods. The existence of the quadruple bond in the structure of I made it possible to demonstrate the mechanism of intercalation of the dirhenium(III) compound. The obtained result is the starting point for the synthesis of mixed $\mathrm{ZrP}$ nanocarriers on the base of quadruple-bonding compounds with promising biological properties.

\section{Acknowledgments}

We are grateful to the Ministry of Education and Science of Ukraine (Grants 0107U000528 and 0111U000111) the studies were supported by.

\section{References}

1. W. J. Roth, B. Gil, W. Makowski, B. Marszaleka and P. Eliasova, Chem. Soc. Rev. 2016, 45, 3400-3438.

DOI:10.1039/C5CS00508F

2. H. Kalita, B. N. Prashanth Kumar, S. Konar, S. Tantubay, M. Kr. Mahto and M. Mandal, Mater. Sci. Eng: C. 2016, 60, 84-91. DOI:10.1016/j.msec.2015.11.010

3. J. Gonzalez-Villegas, Y. Kan, V. I. Bakhmutov, A. Garcia-Vargas, M. Martinez, A. Clearfield and J. L. Colon, Inorg. Chim. Acta. 2017, 468, 270-279. DOI:10.1016/j.ica.2017.05.057

4. A. Diaz, V. Saxena, J. Gonzalez, A. David, B. Casanas, C. Carpenter, J. D. Batteas, J. L. Colon, A. Clearfield and M. D. Hussain, Chem. Commun. 2012, 48, 1754-1756.

DOI:10.1039/c2cc16218k

5. A. A. Marti and J. L. Colon, Inorg. Chem. 2003, 42, 2830-2832. DOI:10.1021/ic025548g

6. A. Diaz, A. David, R. Perez, M. L. Gonzalez, A. Baez, S. E. Wark, P. Zhang, A. Clearfield and J. L. Colon, Biomacromolecules. 2010, 11, 2465-2470. DOI:10.1021/bm100659p

7. A. A. Marti, N. Rivera, K. Soto, L. Maldonado and J. L. Colon, Dalton Trans. 2007, 17, 1713-1718. DOI:10.1039/B618802H

8. A. Clearfield, R. H. Blessingt and J. A. Stynes, J. Inorg, nucl. Chem. 1968, 30, 2249-2258.

DOI:10.1016/0022-1902(68)80224-6

9. U. Costantino, J. Chem. Soc., Dalton Trans. 1979, 2, 402-405. DOI:10.1039/dt9790000402

10. R. Backov, D. J. Jones and J. Roziere, Chem. Commun. 1996, 1, 599-600. DOI:10.1039/CC9960000599

11. F. Carn, A. Derre, W. Neri, O. Babot, H. Deleuze and R. Backov, New J. Chem. 2005, 29, 1346-1350.

DOI:10.1039/b507960h

12. V. Saxena, A. Diaz, A. Clearfield and J. D. Batteas, M. D. Hussain, Nanoscale. 2013, 5, 2328-2336.

DOI:10.1039/c3nr34242e

13. S. Shakshooki, B. E. Ali, S. El-Rais and M. El-Rais, Am. J. Chem. 2014, 4, 22-28.
14. N. Shtemenko, A. Shtemenko Ukr. Biochem. J.. 2017, 89, 5-26. DOI:10.15407/ubj89.02.005

15. N. Shtemenko, K. Domasevich, E. Zabitskaya and A. Golichenko, J. Chem. Soc., Dalton Trans. 2009, 26, 5132-5136. DOI:10.1039/b821041a

16. N. I. Shtemenko, H. T. Chifotides, K. V. Domasevich, A. A. Golichenko, S. A. Babiy, Z. Li, K. V. Paramonova, A. V. Shtemenko and K. R. Dunbar, J. Inorg. Biochem. 2013, 129, $127-$ 134. DOI:10.1016/j.jinorgbio.2013.09.001

17. A. A. Golichenko, K. V. Domasevitch, D. E. Kytova and A. V. Shtemenko, Acta Cryst. 2015, 71, 45-47.

DOI:10.1107/S2056989014026620

18. I. V. Leus, I. A. Klenina, K. A. Zablocka, A. A. Golichenko, A. V. Shtemenko and N. I. Shtemenko, Biopolymers and Cell. 2011, 27, 465-471. DOI:10.7124/bc.000119

19. K. L. Shamelashvili, N. I. Shtemenko, I. V. Leus, S. O. Babiy and O. V. Shtemenko, Ukr. Biochem. J. 2016, 88, 29-39. DOI:10.15407/ubj88.04.029

20. N. Shtemenko, O. Berzenina, D. Yegorova and A. Shtemenko, Chem. Biodivers. 2008, 5, 1660-1667.

DOI:10.1002/cbdv.200890153

21. Y. Zhu, T. Shimizu, T. Kitajima, K. Morisato, N. Moitra, N. Brun, T. Kiyomura, K. Kanamori, K. Takeda, H. Kurata, M. Tafu and K. Nakanishi, New J. Chem. 2015, 39, 2444-2450. DOI:10.1039/C4NJ01749H

22. F. Xia, H. Yong, X. Han and D. Sun, Nanoscale Res. Lett. 2016, 11, 1-7. DOI:10.1186/s11671-016-1559-6

23. E. J. Rivera, C. Figueroa, J. L. Colon, L. Grove and W. B. Connick, Inorg.Chem., 2007, 46, 8569-8576.

DOI:10.1021/ic7006183

24. Z. Li, N. I. Shtemenko, D. Y. Yegorova, S. O. Babiy, A. J. Brown, T. Yang, A. V. Shtemenko and K. R. Dunbar J Liposome Res. 2015, 25, 78-87. DOI:10.3109/08982104.2014.954127

25. I. V. Leus, I. O. Klenina, K. A. Zablotska, O. A. Golichenko, O. V. Shtemenko, N. I. Shtemenko Biopolymers and Cell. 2011, 27, 465-471 (In Ukrainian). DOI:10.7124/bc.000119

26. A.V. Slipkan, D.E. Kytova, A.V. Shtemenko, Ukr. Chem. J. 2017, 83, 35-41 (In Ukrainian).

27. A.V. Slipkan, D.E. Kytova, A.V. Shtemenko, Voprosy khimii i khimicheskoi tekhnologii. 2018, 2, 39-45 (In Ukrainian).

28. S. Shah, Y. Liu, W. Hu and J. Gao, J. Nanosci. Nanotechnol. 2011, 11, 919-928. DOI:10.1166/jnn.2011.3536

29. H. Maeda and Y. Matsumura, Adv. Drug. Deliv. Rev. 2011, 63, 129-130. DOI:10.1016/j.addr.2010.05.001

30. M. Iziumskyi, S. Melnyk and A. V. Shtemenko Chem. Met. Alloys. 2013, 6, 121-124. DOI:10.30970/cma6.0246

31. B. M. Mosby, A. Diaz, V. Bakhmutov and A. Clierfield, ACS Appl. Mater. Interfaces. 2014, 6, 585-592.

DOI:10.1021/am4046553

32. A. Diaz, M. L. Gonzalez, R. J. Perez, A. David, A. Mukherjee, A. Baez, A. Clearfield and J. L. Colon, Nanoscale, 2013, 5, 11456-1146. DOI:10.1039/c3nr02206d 


\section{Povzetek}

$\mathrm{V}$ prispevku poročamo o sintezi kompozita nanodelcev cirkonijevega fosfata $\left(\theta-\mathrm{Zr}\left(\mathrm{HPO}_{4}\right)_{2} \cdot 6 \mathrm{H}_{2} \mathrm{O}(\mathrm{ZrP})\right)$, ki vsebujejo spojino renija(III) (cis- $\mathrm{Re}_{2}\left(\mathrm{C}\left(\mathrm{CH}_{3}\right)_{3} \mathrm{COO}\right)_{2} \mathrm{Cl}_{4} \cdot 2 \mathrm{DMSO}(\mathrm{I})$ ). Proces interkalacije smo spremljali z elektronsko absorpcijsko spektroskopijo (EAS). Na osnovi spektroskopskih podatkov smo sklepali, da so ligandi v okolici klastra direnijevega(III) fragmenta razporejeni v cis konfiguraciji. V predlaganem mehanizmu interkalacije smo predvideli substitucijo aksialnih ligandov I s fosfatnimi skupinami ZrP najprej na površini nanodelcev ZrP, kasneje pa tudi v notranjih plasteh. Dva produkta procesa interkalacije smo karakterizirali z naslednjimi metodami: vrstično elektronsko mikroskopijo (SEM), rentgensko praškovno difrakcijo (XRPD), infrardečo spektroskopijo (FT-IR) in termogravimetrično analizo (TGA). V produktih je bila razdalja med plastmi od 10,53 Å do 16,6 Å, povprečna velikost ploščič pa od $100 \mathrm{~nm}$ do $200 \mathrm{~nm}$. 